\title{
STRUCTURE AND DEBRIS CHARACTERISTICS OF MEDIAL MORAINES IN JOTUNHEIMEN, NORWAY: IMPLICATIONS FOR MORAINE CLASSIFICATION*
}

\author{
By D.M. VERE \\ (Hills Road Sixth Form College, Cambridge CB2 2PE, England) \\ and D.I. BENN
}

(Department of Geography and Geology, University of St. Andrews, St. Andrews KY16 9AL, Scotland)

\begin{abstract}
Four medial moraines on three glaciers in Jotunheimen, Norway, are described. The structure and debris characteristics of the moraines allow three debristransport routes to be identified: (1) discrete concentrated longitudinal septa containing subglacially comminuted debris; (2) diffuse longitudinal septa containing passively englacially transported debris; and (3) supraglacially transported spreads containing rock-fall debris entrained below the firn line. Two of the moraines, occurring down-glacier of nunataks, are nourished by a combination of (1) and (3). The remaining two moraines are nourished solely by englacially transported rock-fall debris (2). Transport routes (1) and (2) represent two distinct types of longitudinal englacial debris septum. The contribution of debris from more than one glacial transport path to single medial moraines indicates the value of a flexible, process-based approach towards moraine classification, with emphasis on the dynamic links between basin morphology, glacial debris entrainment, and moraine characteristics.
\end{abstract}

\section{INTRODUCTION}

Medial moraines are important routeways of debris transport on valley glaciers, and may consist of material from a range of sources. A comprehensive classification was suggested by Eyles and Rogerson (1978) based on the relationship between sediment supply and morphological development. First, ablation-dominant (AD) moraines emerge at the surface as the result of melt-out of englacial debris. Three debris sources were recognized for such moraines: burial in crevasses below the firn line (ADI), firn sedimentation above the firn line (AD2), and elevation of debris in the lee of subglacial rock knobs (AD3). Secondly, ice-stream interaction (ISI) moraines find immediate surface expression via the merging of supraglacial lateral moraines at glacier confluences. Finally, avalanche-type (AT) moraines were identified, originating from persistent supraglacial feeders within single flow units.

Two fundamental debris-transport paths through valley glaciers have been identified by Boulton (1978), each associated with diagnostic debris granulometry, and aggregate clast form and roundness characteristics. First, active transport places debris in traction at the ice-substrate interface. The resulting sediment is characterized by clasts with high roundness, high $c: a$ axial ratios, and a high incidence of facetting and striations (Boulton, 1978; Ballantyne, 1982; Matthews and Petch, 1982). Subglacial abrasion results in high proportions of silt-sized material (Boulton, 1978). Secondly, debris in passive transport in englacial or supraglacial positions is not modified by glacial erosive

\footnotetext{
* Jotunheimen Research Expeditions, Contribution No. 81.
}

processes, but retains the characteristics of the parent clastic material derived by periglacial weathering. Such debris tends to be coarser, and displays lower aggregate roundness and a higher proportion of "slabby" rather than equant, "blocky" clasts (Boulton, 1978; Ballantyne, 1982).

Recent work has shown that each of the fundamental transport paths identified by Boulton may contribute debris to medial moraines, singly or in combination, in ways that cannot be defined simply in terms of the categories of Eyles and Rogerson (1978). Gomez and Small (1985) and Small (1987) have drawn attention to the complex interaction between transport and moraine genesis, and have argued for a more flexible approach to medial moraine classification. They concluded that greater emphasis ought to be placed on the relationships between glacier dynamics, debris supply, and transport mechanisms.

The work reported in this paper extends that of Vere (unpublished) on medial moraines in Jotunheimen, Norway. Data are presented concerning the debris characteristics and structure of four medial moraines that occur on three glaciers in the area (Fig. 1). These data are used to examine the relationship between moraine characteristics and the probable modes of debris entrainment and transport, and indicate the limitations of the existing moraine classification system. The study is principally concerned with two medial moraines that occur in association with nunataks on Storbreen and Tverrabbreen. Information on two other medial moraines, on Storbreen and Søre Illábreen (Fig. 1), is presented for comparative purposes.

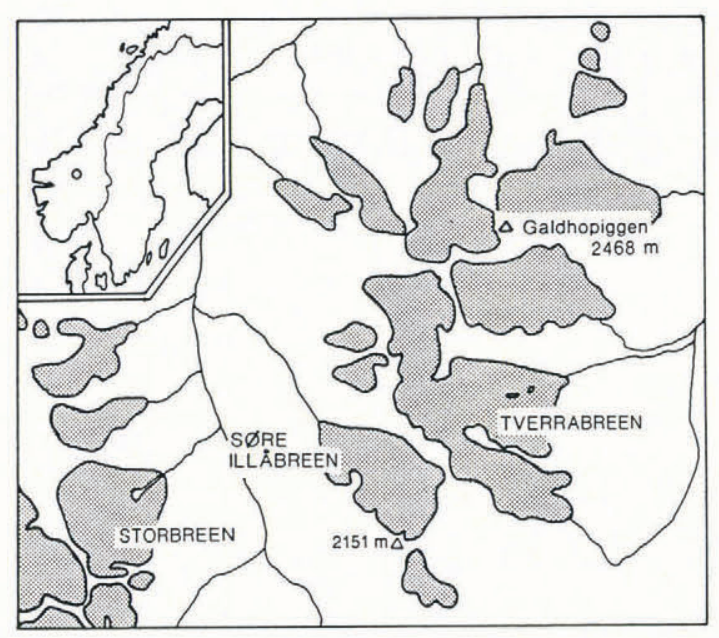

Fig. 1. Location of the study areas. 


\section{STUDY AREAS AND METHODS}

Storbreen, Tverrảbreen, and Søre Illábreen are small valley glaciers that have been in intermittent retreat since the Little Ice Age maximum of c. 1750 A.D. (Hoel and Werenskiold, 1962; Grove, 1988). They are overlooked by steep, of ten precipitous, valley sides rising to over $2000 \mathrm{~m}$ a.s.1. The cuspate plan form of the valley sides divides the upper part of each glacier into a number of small firn basins, giving rise to coalescent flow units, some of which are bounded in the terminal zones by medial moraines. In addition, prominent medial moraines occur on Storbreen and Tverrảbreen in association with low nunataks below the firn lines (Figs 2, 3, and 4). These moraines are the principal focus of the study. The internal structure of the moraines,

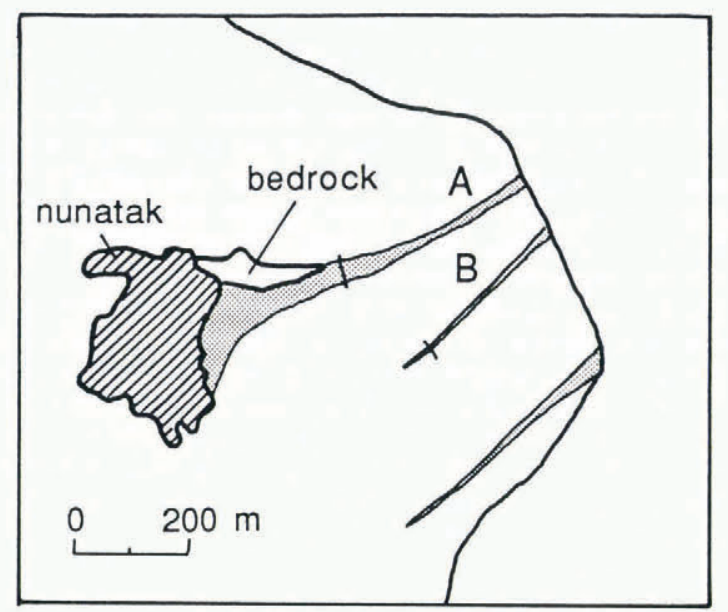

Fig. 2. Snout area of Storbreen, showing the positions of the medial moraines. The locations of the crevasse sections are indicated.

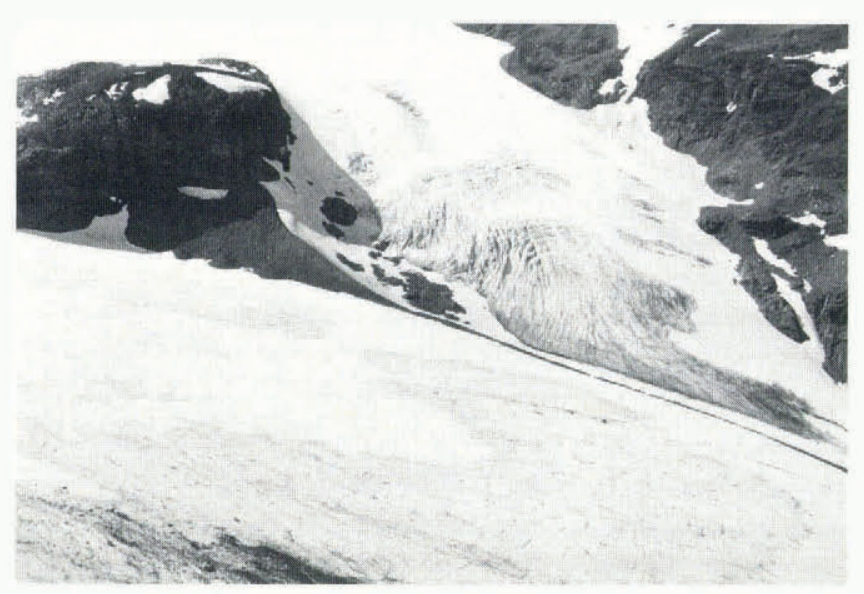

Fig. 3. The Storbreen nunatak and the associated medial moraine. Partially snow-covered bedrock is visible behind the moraine.

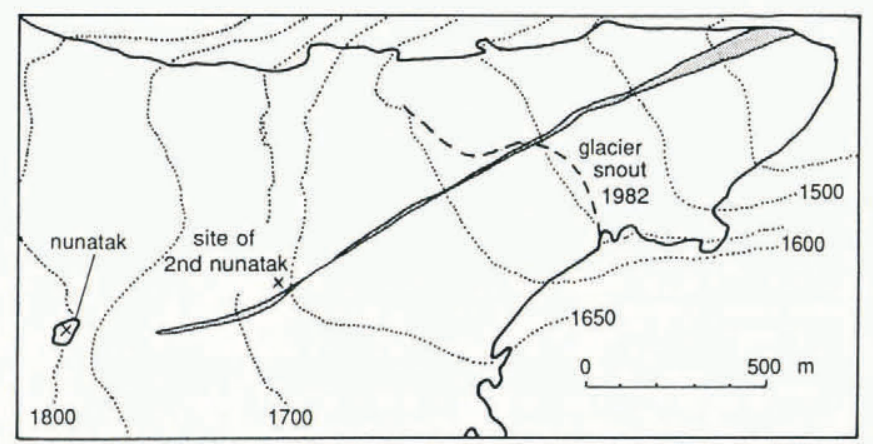

Fig. 4. The snout area of Tverräbreen (after Hoel and Werenskiold, 1962). in addition to that of a less prominent medial moraine on Storbreen, could be recorded due to the presence of transverse crevasses and uneven ablation of the glacier snouts. Observations were also made of the superficial structure of a fourth moraine on Søre Illabreen. The transport history of the debris comprising each of the four moraines was assessed partly in terms of the aggregate form and angularity of samples of clasts and partly through analysis of the granulometry of matrix material $(<4 \mathrm{~mm})$. The long $(a)$, intermediate $(b)$, and short $(c)$ axes of samples of 50 clasts $(a>100 \mathrm{~mm})$ obtained at intervals along the moraines were measured to the nearest $10 \mathrm{~mm}$ to determine aggregate form characteristics, and aggregate roundness was assessed using the scheme of Powers (1953). Samples for granulometric analysis were collected from the same sites. Typical samples are represented graphically in Figures 5, 6 and 7.

STRUCTURE AND DEBRIS CHARACTERISTICS OF THE MORAINES

\section{Storbreen A}

This moraine extends for c. $740 \mathrm{~m}$ down-glacier from the larger of two nunataks (Figs 2 and 3). Ablation at the margin has caused the northern arm of ice to become isolated from the medial moraine, which now lies close to the northern edge of the southern ice stream. Bedrock is exposed in the trough between the two ice streams. The moraine is divisible into three morphological zones: (1) For c. $250 \mathrm{~m}$ down-glacier from the nunatak, the moraine takes the form of a high sharp-crested ridge standing up to $6 \mathrm{~m}$ above the southern ice stream, and diminishing in height down-glacier. Close to the nunatak the moraine lies largely (or wholly) on bedrock (Griffey, 1978), but down-glacier an ice core occurs below a veneer of debris. (2) Between 250 and $340 \mathrm{~m}$ from the nunatak the moraine has lower relief, occurring as a raised ice-cored debris spread centred upon a low, steep-sided longitudinal ridge of poorly sorted matrix-rich debris. This ridge, which has maximum dimensions of $1.5 \mathrm{~m}$ across and $0.5 \mathrm{~m}$ high, is the surface expression of a persistent septum of concentrated debrisrich ice. The septum decreases in width from c. 4 to $0.2 \mathrm{~m}$ between 250 and $280 \mathrm{~m}$ from the nunatak, thereafter decreasing gradually to between 0.05 and $0.1 \mathrm{~m}$. Debris was observed to move laterally from the ridge down the ice-cored slope by a variety of processes, including flow. (3) From $340 \mathrm{~m}$ below the nunatak to the glacier snout the moraine has little or no relief. This is probably primarily the effect of supraglacial melt streams that remove fine material and leave a residual cover of large clasts. The longitudinal septum can be traced down the full length of the zone, and has a relatively constant width, although it swells or pinches out locally.

A transverse crevasse cutting across the moraine in zone $2,280 \mathrm{~m}$ down-glacier from the nunatak, allowed the debris septum to be seen in section (Fig. 5). The sharply bounded septum was flanked by vertically oriented bands of clear and bubbly ice, and englacial particles were not observed more than $0.8 \mathrm{~m}$ from the edges of the septum. The septum itself was $0.1 \mathrm{~m}$ wide at the lowest exposed point (at a depth of $c .3 \mathrm{~m}$ ), widening towards the surface. The zone of most rapid widening was coincident with the position of a thaw front, above which the septum was composed of saturated debris.

Clast characteristics and particle-size curves were determined for samples from the central ridge and the debris cover on lateral parts of the moraine. The clast samples from the ridge (SR1, SR2; Figs 6 and 7) have characteristics typical of actively transported debris. Similarly, the particle-size curves indicate the presence of the products of subglacial abrasion (Fig. 8; cf. Boulton, 1978). By contrast, the samples from the lateral debris cover on the moraine (SD1, SD2) are coarser, and display lower clast roundness and a lower proportion of "blocky" clasts. This debris cover probably has a mixed origin, consisting of material from both active and passive debris-transport paths.

\section{Tverräbreen}

This moraine stretches for $c .1500 \mathrm{~m}$ down-glacier from a nunatak. In 1927, the moraine emerged c. $250 \mathrm{~m}$ down- 
glacier from the nunatak, and a second rock knob that protrudes at present through the moraine was marked only by a local ice steepening (Hoel and Werenskiold, 1962; Fig. 4). For most of its length, the moraine is a low icecored ridge standing above the adjacent clean ice. The ridge is centred upon a longitudinal debris septum. In 1987, this was well exposed in two sections in the walls of a collapsed melt-water tunnel. The septum was sharply bounded, $c$. $0.1-0.2 \mathrm{~m}$ across, and consisted of frozen matrix-rich debris. Alternating vertical foliae of clear and bubbly ice lay parallel to the margins of the septum.

The aggregate-clast characteristics and granulometric curves of samples from the moraine show a similar pattern

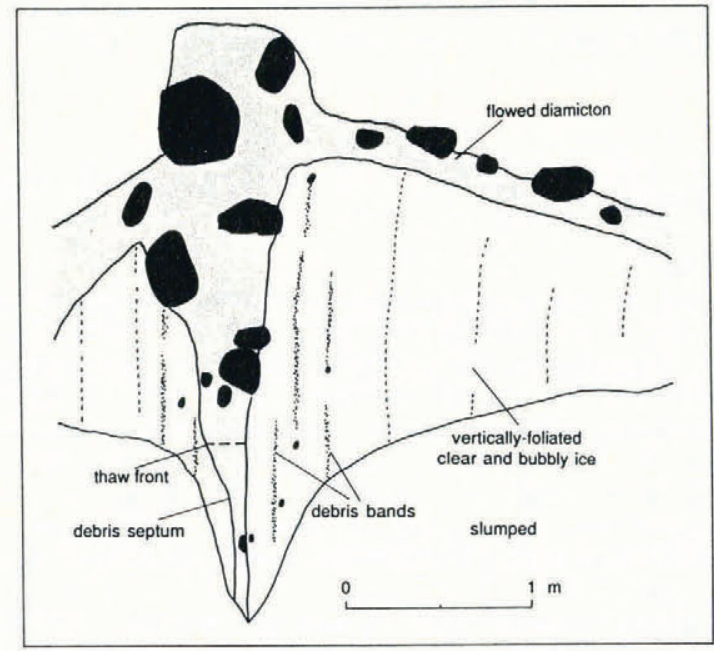

Fig. 5. Storbreen A: crevasse section. Note the relationship between the central ridge and the sub-surface debris septum. to those from Storbreen A (Figs 6, 7, and 8). The samples from the ridge crest (associated with the septum: TR1, TR2) are indicative of a history of subglacial comminution, while those from the debris cover in lateral positions on the moraine (TD1, TD2) suggest an additional passively transported component.

\section{Storbreen B}

This moraine, which crops out on the lowermost $400 \mathrm{~m}$ of the glacier, lies $100-200 \mathrm{~m}$ south-east of Storbreen A (Fig. 2). The most likely debris source is a steep rock buttress that descends from a $2077 \mathrm{~m}$ peak above the valley back wall. At its point of emergence, the moraine consists of two diffuse longitudinal bands of coarse debris. A third debris band emerges $250 \mathrm{~m}$ from the snout, and the moraine then becomes a continuous spread with a constant width of c. $12 \mathrm{~m}$ (Fig. 9). The moraine is not a positive relief feature. Clast concentration gradually increases down-glacier, but the cover nowhere exceeds two-three clasts in thickness. Debris concentration in the ice beneath the debris cover tends to be extremely low. The sub-surface structure of the moraine was observable in a deep transverse crevasse $300 \mathrm{~m}$ from the snout. No concentrated septum was observed, with debris only occurring as scattered diffuse clusters of sand and gravel particles in otherwise clean ice.

Form and roundness data for two samples from the moraine are shown in Figure 6. The high proportion of angular and very angular clasts with low $c .: a$ axial ratios is typical of periglacially shattered debris (Ballantyne, 1982; Matthews and Petch, 1982; Vere, unpublished), and is indicative of passive glacial transport. The coarse nature of the material also indicates that glacial comminution has not affected the debris in the moraine.

\section{Søre Illåbreen}

A number of medial moraines occur in the terminal area of Søre Illabreen, and at least one of these incorporates an inclined concentrated debris septum. The

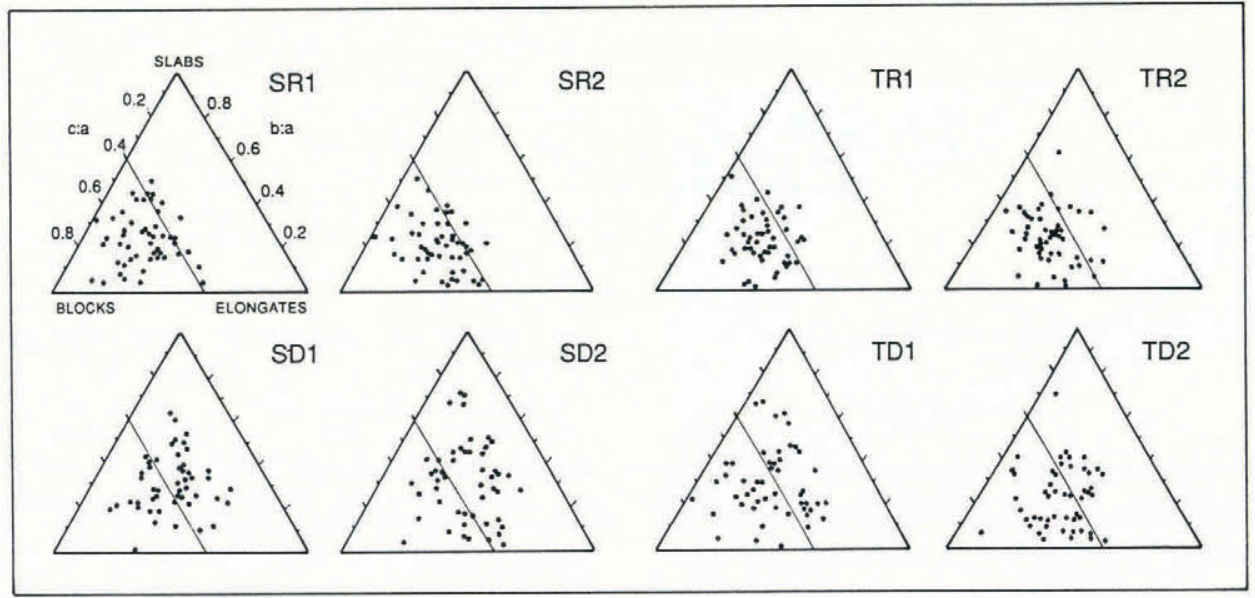

$\mathbf{a}$

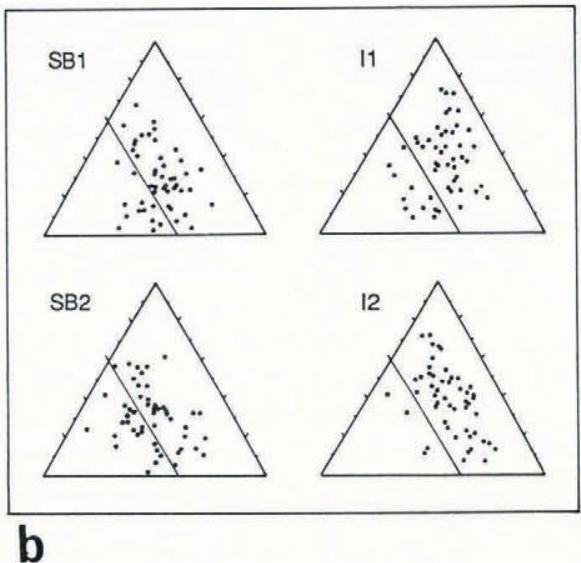

Fig. 6. a. Form ternary diagrams for Storbreen $A$ and Tverräbreen. $S R$ and $T R$ refer to samples from the central debris septa, SD and TD to samples from lateral parts of the moraines. $N=50$. For further explanation see text. b. Form ternary diagrams for the Storbreen $B(S B)$ and Søre Illabreen (I) samples. $N=50$. Key as for Figure 5. 


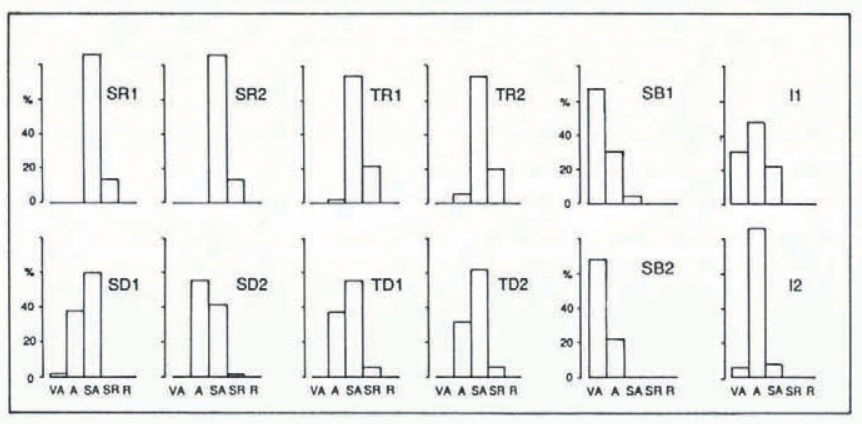

Fig. 7. Roundness histograms for the moraine samples. VA, very angular; $A$, angular; $S A$, sub-angular; $S R$, sub-rounded; $R$, rounded. $N=50$.

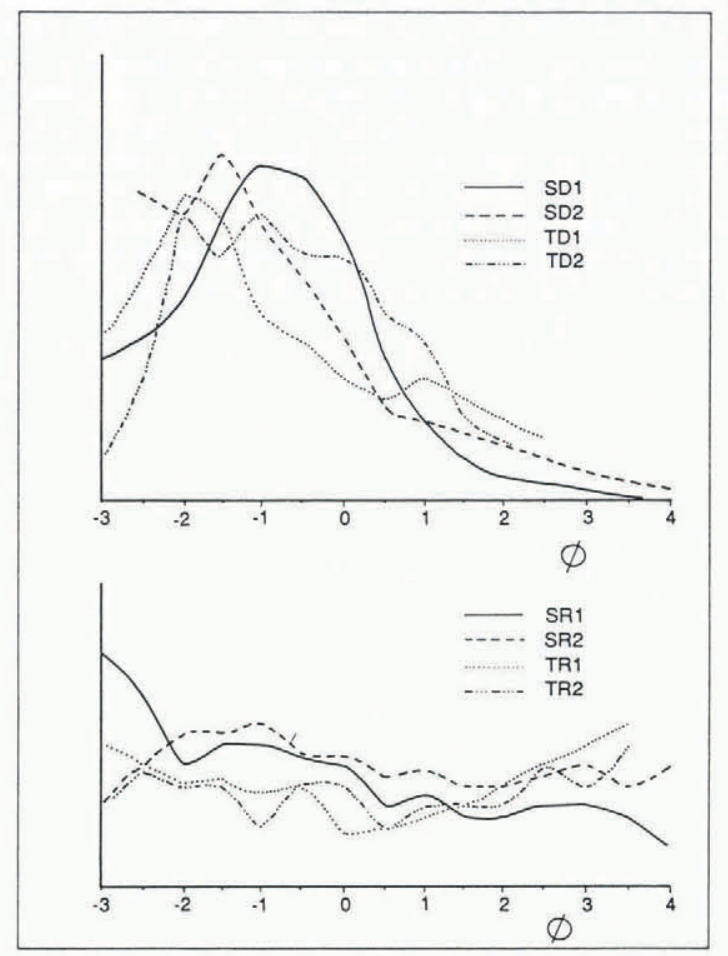

Fig. 8. Particle-size curves for matrix material from the moraine samples. Each curve represents one sample. The curves are smoothed frequency histograms and show the relative distribution of particle sizes in the samples. Horizontal scale in $\phi$ units.

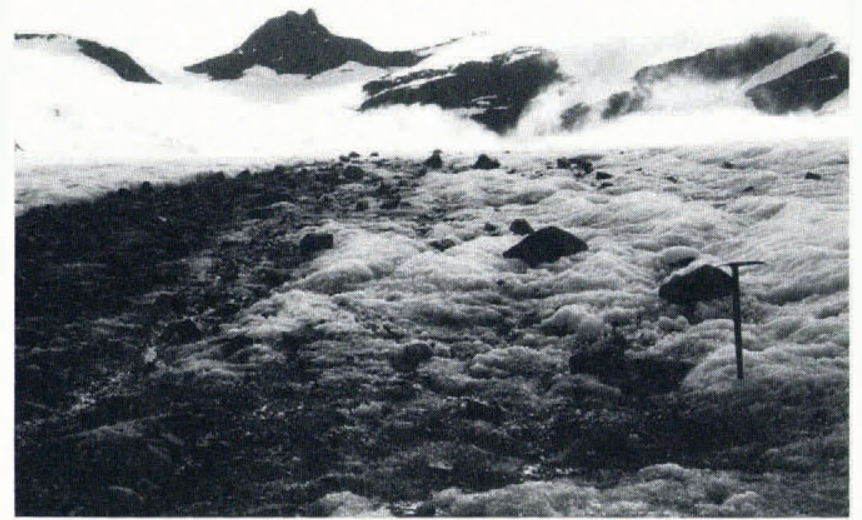

Fig. 9. Superficial debris on Storbreen B. The debris probably originates from one of the nunataks in the background. moraine investigated in this study emerges c. $300 \mathrm{~m}$ from the snout and is probably associated with a steep rock buttress that descends into the glacier accumulation area from a $2151 \mathrm{~m}$ peak on Tverrbotntindan (Fig. 1). The moraine attains maximum dimensions of $c .7 \mathrm{~m}$ wide and $0.5 \mathrm{~m}$ high. It initially emerges as a single diffuse row of periodotite clasts, gradually increasing in concentration down-glacier. The debris characteristics are similar to those sampled from Storbreen B, and indicate that the moraine is composed of passively transported supraglacially derived sediment (Figs 6 and 7). Material showing evidence of subglacial transport crops out in a transverse debris band close to the snout (Vere, unpublished), but is considered to have been elevated along a marginal shear plane not genetically connected with the medial moraine.

\section{INTERPRETATION: DEBRIS TRANSPORT AND MORAINE GENESIS}

Storbreen $\mathrm{A}$ and the Tverrảbreen moraine

The debris characteristics from the concentrated septa in these moraines are typical of subglacially comminuted material. Furthermore, the form of the septa and the flanking foliated ice strongly resembles that of the basal layers of temperate glaciers (Boulton, 1974; Souchez and Lorrain, 1987). The septa are therefore interpreted as the basal transport zones of adjacent ice streams that have been re-oriented into vertical positions in the lee of the nunataks (cf. Boulton, 1978; Gomez and Small, 1985). The magnitude and form of the massive rock-floored part (zone 1) of Storbreen A suggest that it may have primarily accumulated subglacially in the lee of the nunatak. If this is so, the association between the zone 1 debris accumulation and the englacial debris septum may reflect a genetic relationship between elevated basal debris and certain streamlined depositional forms, as postulated by Boulton (1976, 1978).

Upstanding silt-rich debris ridges, similar to those in zone 2 of Storbreen A, have been described by other authors. Gomez and Small (1985) described "... compacted ridges of silt-sized material" on Haut Glacier d'Arolla, and considered these to have been squeezed out of a sub-surface septum by lateral pressures. An origin by squeezing for the debris ridge on Storbreen appears improbable for two reasons. First, the retreat of the northern arm of ice from the vicinity of the moraine has removed significant lateral confining pressures that could have been responsible for squeezing. Secondly, the evidence from the crevasse section indicates that the ridge is continuous with the thawed upper part of the debris septum, where it has been widened by ablation. It is suggested that the consolidation of the material in the ridge is due to the saturation and subsequent desiccation of debris supplied from the septum by ablation. The consequent strength of the ridge would account for its temporary survival as a relief feature.

The characteristics of the debris from the lateral parts of both moraines are intermediate between those from the concentrated septa and passively transported material (Fig. 6), indicating a mixed origin. The passively transported components are clearly derived from frost-shattered material that has fallen from the precipitous lee slopes of the nunataks. Because the nunataks occur below the firn lines of the glaciers, net snow burial of rock-fall debris does not occur, although limited debris ingestion may occur in randklufts on Tverrảbreen. Therefore, the greater part of the debris does not enter englacial transport but is carried on the glacier as a superficial veneer. Actively transported debris is added to the supraglacially derived components by surface-slope processes. Material melting out of the concentrated debris septa travels down the ice-cored slopes of the moraines by flow and other processes, whereupon it mixes with the material derived directly from the nunataks. The presence of lateral slopes, and the consequent debris mobilzation, is the result of differential glacier-surface ablation due to the locally high debris supply (cf. Small and Clark, 1974).

\section{Storbreen B and the Søre Illåbreen moraine}

A simple history is indicated for these moraines. None of the debris shows evidence of subglacial transport, and this material is consequently interpreted as entirely 
supraglacial in origin. The pattern of debris emergence on the glacier surfaces and the evidence from the crevasse cutting the Storbreen B moraine suggest that the most likely debris-entrainment mechanism is annual burial above the firn line of rock-fall debris derived from persistent sources on the valley back walls (cf. Rogerson and others, 1986). The lack of significant positive relief of the moraines is a reflection of low debris concentrations.

\section{CONCLUSIONS}

The data presented here support the conclusions of Gomez and Small (1985) that medial moraines cannot be simply categorized using the scheme of Eyles and Rogerson (1978). For the four moraines discussed in this paper, three debris-transport paths can be identified, corresponding to three of the models defined by Eyles and Rogerson. (1) Basal debris is elevated into discrete longitudinal septa which, upon glacier ablation, supply material to the surface (AD3). (2) Rock-fall debris is transported englacially in diffuse septa after seasonal burial above the firn line. Below the firn line, the debris accumulates on the glacier surface (AD2). (3) Rock-fall debris is transported wholly supraglacially after entrainment below the firn line (ISI). The Tverrábreen moraine and Storbreen A moraine originated by a combination of (1) and (3), while the Søre Illábreen moraine and Storbreen B moraine consist solely of englacially transported rock-fall debris (2). The occurrence of debris from more than one transport path in a single medial moraine shows that the models defined by Eyles and Rogerson (1978) are best regarded as a set of fundamental classes, combinations of which contribute to specific moraines in the field. Combinations other than that described in this paper may also be envisaged. This approach to medial moraine classification is implicit in the flow diagram presented by Gomez and Small (1985), in which debris-transport paths are regarded as complementary, rather than mutually exclusive, in medial moraine formation.

The present results also suggest a sub-division of longitudinal debris septa into concentrated septa (Storbreen A, Tverrảbreen) and diffuse septa (Storbreen B, Søre Illäbreen), a classification based on debris density and the clarity of septum boundaries. The data imply that a systematic relationship may exist between the structure of debris septa and the characteristics of constituent debris, with concentrated septa being associated with actively transported debris and diffuse septa being composed of passively transported rock-fall debris. The patterns noted in this paper indicate that both structure and debris characteristics are related effects of the mechanisms of debris entrainment, which themselves are controlled by basin morphology, glacier form, and the location of debris sources. In turn, on the moraines under study, structure and debris concentration exert a control on the development of moraine relief (cf. Small and Clark, 1974; Small, 1987). Ideally, a comprehensive classification of medial moraines should reflect the links between process and morphology at a range of scales from the glacierized basin to morainic debris.

\section{ACKNOWLEDGEMENTS}

This work was funded by grants from Coventry
Polytechnic (to D.M.V. and D.I.B.), the British Geomorphological Research Group (to D.M.V. and D.I.B.), the Dudley Stamp Memorial Fund (to D.M.V.), and the Manchester Geographical Society (to D.M.V.). We are particularly grateful to S. Heslop for the collection of additional data in 1988. Assistance in the field was also given by G. Duller. Dr C.K. Ballantyne, Dr J. Jarvis, and two anonymous referees made constructive comments on earlier drafts of the manuscript.

\section{REFERENCES}

Ballantyne, C.K. 1982. Aggregate clast form characteristics of deposits near the margins of four glaciers in the Jotunheimen massif, Norway. Nor. Geogr. Tidsskr., 36(2), 103-113.

Boulton, G.S. 1974. Processes and patterns of glacial erosion. In Coates, D.R., ed. Glacial geomorphology. Binghamton, NY, State University of New York, 41-87.

Boulton, G.S. 1976. The origin of glacially fluted surfaces observations and theory. J. Glaciol., 17(76), 287-309.

Boulton, G.S. 1978. Boulder shapes and grain-size distribution as indicators of transport paths through a glacier, and till genesis. Sedimentology, 25, 773-799.

Eyles, N. and R.J. Rogerson. 1978. A framework for the investigation of medial moraine formation: Austerdalsbreen, Norway, and Berendon Glacier, British Columbia, Canada. J. Glaciol., 20(82), 99-113.

Gomez, B. and R.J. Small. 1985. Medial moraines of the Haut Glacier d'Arolla, Valais, Switzerland: debris supply and implications for moraine formation. J. Glaciol., 31(109), 303-307.

Griffey, N.J. 1978. Lichen growth on supraglacial debris and its implications for lichenometric studies. J. Glaciol., 20(82), 163-172.

Grove, J.M. 1988. The Little Ice Age. London, Methuen.

Hoel, A. and W. Werenskiold. 1962. Glaciers and snowfields in Norway. Nor. Polarinst. Skr. 114.

Matthews, J.A. and J.R. Petch. 1982. Within-valley asymmetry and related problems of neoglacial lateral moraine development at certain Jotunheimen glaciers, southern Norway. Boreas, 11(3), 225-247.

Powers, M.C. 1953. A new roundness scale for sedimentary particles. J. Sediment. Petrol., 23, 117-119.

Rogerson, R.J., M.E. Olson, and D. Branson. 1986. Medial moraines and surface melt on glaciers of the Torngat Mountains, northern Labrador, Canada. J. Glaciol., 32(112), 350-354.

Small, R.J. 1987. Englacial and supraglacial sediment: transport and deposition. In Gurnell, A.M. and M.J. Clark, eds. Glaciofluvial sediment transfer: an alpine perspective. Chichester, etc., John Wiley and Sons, $111-145$.

Small, R.J. and M.J. Clark. 1974. The medial moraines of the lower Glacier de Tsidjiore Nouve, Valais, Switzerland. J. Glaciol., 13(68), 255-263.

Souchez, R.A. and R.D. Lorrain. 1987. The subglacial sediment system. In Gurnell, A.M. and M.J. Clark, eds. Glaciofluvial sediment transfer: an alpine perspective. Chichester, etc., John Wiley and Sons, 147-164.

Vere, D.M. Unpublished. Depositional characteristics of ice-marginal landforms, Jotunheimen, Norway. (Ph.D. thesis, Coventry Polytechnic, 1986.) 